Chirurgia (2018) 113: 809-825

No. 6, November - December

Copyright $\odot$ Celsius

http://dx.doi.org/10.21614/chirurgia.113.6.809

\title{
Use of the Stomach in Esophageal Reconstructive Surgery in Era of Minimally Invasive Approach
}

\author{
Silviu Constantinoiu, Florin Achim, Adrian Constantin
}

General and Esophageal Surgery Clinic, Center of Excellence in Esophageal Surgery, Sf. Maria Clinical Hospital, Bucharest, Romania

Carol Davila University of Medicine and Pharmacy, Bucharest, Romania

Corresponding author:

Florin Achim, MD

Center of Excellence in Esophageal

Surgery, "Sf. Maria" Clinical Hospital

Bucharest, Romania

E-mail: achim.florin@yahoo.com

\section{Rezumat}

Utilizarea stomacului în chirurgia reconstructivă esofagiană în era abordului minim invaziv - tehnică operatorie

Esofagectomia este indicația standard pentru tratamentul chirurgical al cancerului esofagian, însă aceasta poate fi efectuată şi în cadrul managementului unor afecțiuni benigne. Esofagectomia este urmată de reconstrucția esofagiană utilizând alte segmente ale tubului digestiv şi este asociată cu o morbiditate şi mortalitate postoperatorie crescute. Interpunerea gastrică cu anastomoza eso-gastrică intratoracică sau cervicală este, în prezent, tehnica preferată de reconstrucție după esofagectomie. Incidența esofagectomiei efectuată prin abord minim invaziv a crescut în ultimii ani datorită tehnologiei avansate a chirurgiei endoscopice şi a amplificării imaginii ce oferă o estimare mai bună a planurilor anatomice, facilitează accesul în spații restrânse şi practicarea unei disecții mai precise cu traume mai mici ale țesuturilor. Studiile clinice randomizate au constatat o reducere semnificativă a complicațiilor postoperatorii pulmonare, scăderea duratei de spitalizare, dar şi rezultate oncologice echivalente esofagectomiei clasice. Prezentăm tehnica operatorie a esofagectomiei integral minim invazive efectuate în clinica noastră prin triplul abord McKeown modificat toracoscopic laparoscopic şi cervical cu reconstrucție esofagiană cu stomac.

Cuvinte cheie: cancer esofagian, esofagectomia minim invazivă, reconstrucție esofagiană cu stomac 


\begin{abstract}
Esophagectomy is standard indication for surgical treatment of resectable esophageal cancer, but it can also be performed for the management of benign conditions. Esophagectomy is followed by esophageal reconstruction using other parts of the digestive tract and is associated with increased postoperative morbidity and mortality. Gastric interposition with intrathoracic or cervical esophago-gastric anastomosis is currently the preferred technique for reconstruction after esophagectomy. The incidence of esophagectomy performed by the minimal invasive approach has increased in recent years due to the advanced technology of endoscopic surgery and image enhancement that provides a better estimate of anatomical plans, facilitates access to narrow spaces and more precise dissection with less tissue trauma. Randomized clinical trials have found a significant reduction in postoperative respiratory complications, decreased hospital stay and equivalent oncological results to open esophagectomy. We present the operative technique of minimally invasive esophagectomy performed in our clinic by three-stage modified McKeown approach thoracoscopic, laparoscopic and cervical with esophageal reconstruction with stomach.
\end{abstract}

Key words: esophageal cancer, minimally invasive esophagectomy, esophageal reconstruction with stomach

\section{Short History of Esophageal Reconstruction with Stomach}

In order to understand the status and the role of the minimally invasive approach in the surgical treatment of the esophageal neoplasm and in the same time, the difficulties encountered in implementation in current practice, we must mention the evolution of the technique of esophagectomy in the last 100 years.

Since the first subtotal transthoracic esophagectomy with cervical esophagostomy and feeding gastrostomy (the patient used for feeding a rubber tube connected to the two stomas) performed by Franz Törek, in 1913, many reconstruction techniques have been attempted to find the ideal substitute for resected esophagus (1). The stomach is the primary organ in the replacement of the esophagus after esophagectomy for cancer. It has a sufficient length (subsequent reduced anastomotic tension), it has a rich vascularization, and only one anastomosis is performed to restore digestive continuity, an important aspect for postoperative evolution after extensive surgery in patients with malnutrition (2). Note that when the stomach is not available for reconstruction (gastric resections or post-caustic lesions in the past surgical history), the jejunum and colon are feasible alternatives.

In 1905, in Cleveland (USA), Claude Beck and Amza Jianu in Bucharest (Romania), in 1912, created an anisoperistaltic feeding tube from the greater gastric curvature (BeckJianu gastrostomy) which was later used in the esophageal reconstruction. The presternal anisoperistalic tube did not reach the neck, and a cutaneous tube (using the Bircher method) was interposed to achieve digestive continuity (without qualities of the gastrointestinal tract, the tube was exposed to fistulization) $(3,4)$.

In 1920, M. Kirschner published a reconstruction technique using the stomach mobilized after sectioning of the left gastric artery, the left gastroepiploic artery and the short gastric vessels, so the main nutritional gastric artery was the right gastroepiploic artery, the terminal artery of the gastroduodenal artery, branch of the common hepatic artery (5). The first stomach reconstruction after an esophageal cancer resection was successfully performed in Japan by T. Ohsawa in 1933 (6).

The modern era of open esophagectomy (OE) began immediately after the Second World War, when technological developments 
in the medical field (general anesthesia with orotracheal intubation) and the use of antibiotics allowed performing OE with good results with the restoration of digestive continuity during the same surgery.

In 1946, Ivor Lewis described two-stage esophagectomy (laparotomy and right thoracotomy) and reconstruction with stomach accessioned intrathoracic (7). In 1951, in Romania, Dan Gavriliu performed the first reconstruction with anisoperistaltic gastric tube from the greater curvature with cervical esofago-gastric anastomosis without cutaneous tube interposition. The technical artifice involved the improvement of a procedure (originally used by Amza Jianu) by adding splenectomy in the hilum (resulting a longer gastric tube) and the dissection of the tail and body of pancreas to the aorta with the splenic artery becoming the arterial supply of the anisoperistaltic gastric graft.

In 1954, at Mount Sinai Hospital, New York, JH. Garlock reported a 38\% postoperative mortality after performing 92 esophageal resections. In the same year, SH. Sweet published OE results in a 287 patients with a postoperative mortality of $18 \%$ (9-10). In 1959, in Japan, K. Nakayama (a former Oshawa's resident) reported a postoperative mortality rate of only 8\% in 953 esophageal resections (11).

In 1976, K. McKeown described the technique of the three-stage approach thoracic, abdominal and cervical with esophageal reconstruction with gastric pull-up and end-to-side esophagogastric anastomosis (12). The trans-hiatal approach described first by G. Turner (1933) was updated by M. Orringer and H. Sloan (1978) to avoid complications associated with the transthoracic approach $(13,14)$.

The post-operative 30-day post-operative morbidity, achieved by H. Akiyama in Japan in 210 patients treated by open approach, has not been accomplished elsewhere in the world (15).

At the time of introducing minimally invasive surgery in the western world (1992), open esophagectomy was associated with a postoperative mortality rate of $5-11 \%$ and a 5 -year survival rate of $14-22 \%(16-17)$. Nowadays, the postoperative morbidity associated with $\mathrm{OE}$ in experienced centers is $42 \%-50 \%$, and the mortality at 30 days postoperatively is $2.85 \%$ $4.3 \%$ (18).

Twenty-six years ago, the first thoracoscopic esophagectomy was successfully performed by Cuschieri et al. (19). In the following years, minimally invasive esophagectomy (MIE) was initially done by a combined hybrid approach (video-assisted thoracic surgery - VATS with laparotomy or right thoracotomy with handassisted laparoscopic surgery - HALS), followed by robotic-assisted minimally invasive esophagectomy - RAMIE). Recently, in the Netherlands, the MIE has become the standard indication for the treatment of resectable esophageal cancer (20).

The first postoperative MIE results were equivalent to the traditional approach. Initially, this finding in conjunction with the difficulties associated with the cost of the new endoscopic technology and with concerning about the possible adverse effects on oncological outcomes determined some centers to be hesitant to abandon standardized open techniques and they did not find sufficient motivation to implement the MIE.

However, the introduction of thoracoscopy and laparoscopy in current practice has led to an important global competition between renowned centers in esophageal surgery to reproduce in minimally invasive fashion the OE stages or to discover new technical variants (MIE in prone position).

Totally minimally invasive esophagectomy is technically difficult and requires a long learning curve. For the esophagectomy through the three-stage approach thoracoscopic, laparoscopic and cervical, at least 35 surgeries should be performed to overcome the learning curve and more than 100 surgical interventions for the two-stage approach laparoscopic and thoracoscopic with gastric tube reconstruction $(22,23)$. Experience in open esophageal surgery and advanced technical skills in minimally invasive surgery reduce the learning curve (we benefited from this aspect).

Regardless of the type of surgical approach used, classic or minimally invasive, restoring the digestive continuity after esophagectomy is not always easy. Among the esophageal reconstruction models with gastric conduit 
currently used, we mention the use of the whole stomach, a technique perfected by Nakayama, which is the first variant of the esophagus replacement. This technique has the disadvantages associated with intrathoracic gastric reservoir transposition such as reflux or increased tracheobronchial aspiration. Creating of gastric tube by the Akiyama technique (from the large gastric curvature) is the second option (when the resection of the lesser curvature must be performed due to oncological reasons - distal esophageal neoplasm, celiac lymph nodes), when there is a poor arterial perfusion in the gastric conduit or is the preferred technique of the surgeon (24).

Clinical trials, systematic reviews and metaanalyses compared the outcomes (anastomotic leakage rate, the incidence of anastomotic stenosis, reflux, pneumonia, delayed gastric emptying, and intrathoracic stomach syndrome) of the both variants to establish the ideal surgical technique for esophageal reconstruction. Some clinical trials have highlighted the benefits of using the entire stomach to provide better protection for vessels in gastric submucosa (cutting them during creation the gastric tube would significantly affect gastric venous return circulation) $(25,26)$.

Other studies have shown the adaptability of the anatomical structure of the gastric tube to functional needs and the reduction of postoperative fistular complications due to the reduction of anastomotic tension, especially in the case of neck anastomoses (27).

In the last 30 years, at the General and Esophageal Surgery Clinic in St Maria Hospital Bucharest, the open esophagectomy was performed for the treatment of esophageal cancer with immediate and long-term results comparable to other centers due to the vast experience in esophageal pathology. Since 2015, in order to reduce the rate of postoperative respiratory complications, we have introduced minimally invasive esophagectomy in every day practice, originally performed by the three-stage modified McKeown approach (thoracoscopic, laparoscopic and cervical) with esophageal reconstruction with gastric pull-up and extracorporeal preparation of the gastric graft through a epigastric mini-laparotomy, subsequently through a totally minimally invasive minimal approach.

The three-stage modified McKeown approach provides an excellent visual field for mediastinal lymphadenectomy and avoids complications associated with intrathoracic anastomotic fistula that can cause high postoperative morbidity and mortality. We prefer to perform this approach, although the cervical esophago-gastric anastomosis is associated with significant problems of tracheobronchial swallowing and aspiration that may increase the risk of respiratory complications, does not affect vital prognosis. Also, fistular complications can be treated conservatively with endoscopic interventions (Endosponge, coated stents) and the anastomotic stenosis (consequence of healing of the fistula) can be dilated with Savary bougies under x-ray control.

In the last 3 years, we performed this operation using a $2 \mathrm{D}$ camera and recent $3 \mathrm{D}$ HD video camera, with lower respiratory and parietal complications, with a short length of admission to Intensive Care Unit (ICU) and reduced hospital stay compared to classic esophagectomy. The mortality rate in the first 30 days postoperatively was equivalent to the open approach. Short term oncology results are also similar.

\section{Preoperative Clinical and Para Clinical Evaluation}

Besides, the clinical examination, all patients with suspicion of esophageal neoplasm are evaluated endoscopically (EGD), radiologically, ecoendoscopically (rarely fine needle aspiration - FNA) and tomographic (CT) to assess the extent of the disease. The CT-PET scan is not a routine investigation in our clinic, although this could prevent a surgery without oncological benefit. We use for staging the seventh edition of the American Joint Committee on Cancer (AJCC) (29).

EGD and barium swallow used in restadialization in patients who received neoadjuvant treatment, in addition to obtaining details of tumor topography, assesses the 
future gastric conduit in the perspective of esophageal reconstruction. The CT thorax and abdomen assesses the esophageal tumor response to neoadjuvant treatment or may detect the presence of metastasis.

Because of reduced oral intake associated with dysphagia, it is often necessary to use a feeding tube for adequate nutritional support in patients with esophageal neoplasms treated with multimodal therapy. The insertion of a feeding tube can be done endoscopically, laparoscopically or by a classic approach and has associated a known morbidity for these procedures (dislocation of gastrostomy, obstruction of feeding jejunostomy, intestinal obstruction) requiring special care or emergency surgeries. Any of the procedures listed must also to consider the subsequent options of reconstruction.

Preoperative preparation evaluates renal and liver function, haemogram and coagulation. Chest X-ray, EKG, spirometry and nasal, oropharyngeal and rectal probes are taken. The patient also initiates breathing exercises and low molecular weight heparin (LMWH) is given the day before the operation.

\section{Operative Technique}

We present the technique of minimally invasive esophagectomy through the modified McKeown approach thoracoscopic, laparoscopic and cervical with gastric pull up through the posterior mediastinum and end-to-side esophagogastric anastomosis. The instruments of our department consists of the standard HD 3D laparoscopic surgery kit, 10$12 \mathrm{~mm}$ trocars, $45 \mathrm{~mm}$ EndoGIA vascular stapler with a white or gray cartridge (for the arch of azygos vein and left gastric artery), 5 $\mathrm{mm}$ endoscopic Ligasure instruments or ultrasonic dissector and EndoFan retractor. In order to reduce the duration of surgery, we use linear GIA and EndoGIA staplers of a $60 \mathrm{~mm}$ blue or green cartridge depending on the thickness of the gastric wall for extracorporeal preparation of the gastric graft when performing the lesser curvature resection with the creation of the gastric tube. For the thoracoscopic approach, we used the left lateral decubitus position and the supine position for the laparoscopic and cervical approach.

We use an epidural catheter for additional analgesia. After fitting the epidural catheter and the onset of general anesthesia with selective orotracheal intubation with the Carlens tube, we introduce intra-esophageal a thick Faucher tube that will be useful during mediastinal dissection of the esophagus. With the right lung exuflated by selective intubation, the thoracoscopic stage begins and the patient is positioned in the left lateral decubitus (for opening the intercostal spaces, the operating table is angled additional or a pile is used at the base of the left hemithorax) and the insertion of the optical trocar and trocars in the right hemithorax, so that the distance between them is sufficient, avoiding as much as possible conflicts between surgical instruments during surgery.

After performing a small incision in the 8th intercostal space on the middle axillary line, the optical trocar is introduced and penetrated into the pleural cavity through the intercostal muscles in pleura using an Optiview ${ }^{\circledR}$ trocar that allows a direct view of the anatomical layers and is avoided lesion of lung parenchyma in the presence of pleural adhesions.

Four working trocars are used as follows: a $12 \mathrm{~mm}$ trocar in the $9^{\text {th }}$ intercostal space behind the posterior axillary line; a $12 \mathrm{~mm}$ trocar in the $7^{\text {th }}$ intercostal space, anterior to the anterior axillary line; a $12 \mathrm{~mm}$ trocar in the $4^{\text {th }}$ intercostal space on the anterior axillary line for the "fan" endoscopic spacer; a $5 \mathrm{~mm}$ trocar anterior and inferior to the tip of the shoulder blade (Fig. 1). We note that all the presented intraoperative images belong to the collection of the Center of Excellence in Esophageal Surgery, Sf. Maria Clinical Hospital Bucharest.

During the first surgeries, we encountered difficulties in finding the optimal position for stapling the arch of azygos vein, thus using a 12 $\mathrm{mm}$ working trocar, the vascular cartridge stapler can be inserted through any one of them. Any dysfunction related to the use of instruments adds additional stress to the 


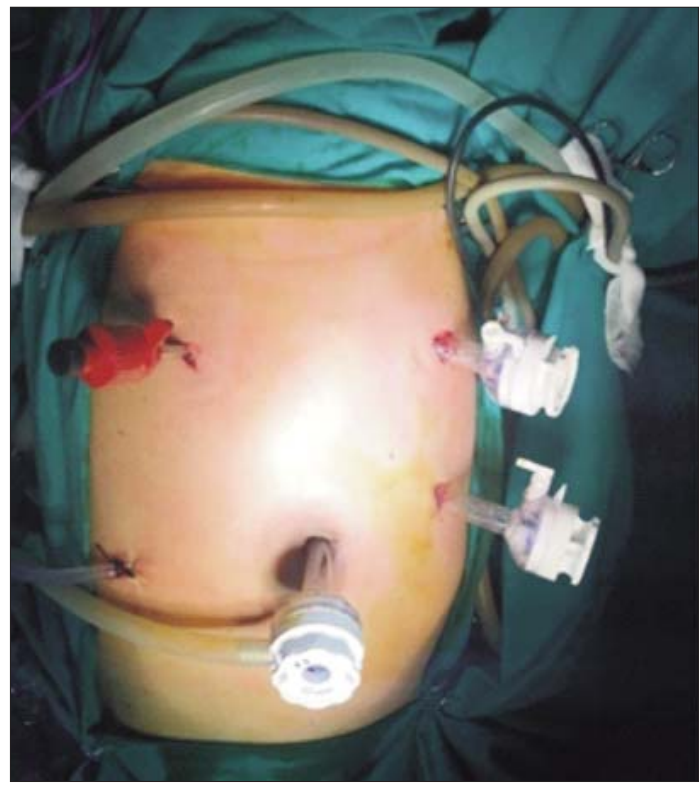

Figure 1. The position of trocars during thoracoscopy

surgical team, which performs a long-hours operation. Also, with regard to the $5 \mathrm{~mm}$ trocar, most of the time during the thoracoscopic stage, it is not used due to the fixed position of the intrathoracic organs, a single traction instrument being sufficient for tissue traction. Also, if this trocar is positioned too posteriorly it is completely useless because the instruments introduced by this trocar will encounter the vertebral bodies in the path to the posterior mediastinum and in this case, it has to be repositioned. We intend to use three working trocars in the future. After the right lung is collapsed, the anatomical elements are identified: the azygos vein, thoracic esophagus, the main right and left bronchi, the trachea, the pulmonary pedicles. For additional lung collapse, insufflation with $\mathrm{CO} 2$ up to a pressure of $8 \mathrm{mmHg}$ can be used. The macroscopic appearance of the esophagus is assessed in order to highlight any signs of extra-adventitial invasion or perisophageal lymph nodes.

Incision of the triangular ligament and mediastinal pleura superior and inferior to the arch of azygos vein and carefully dissected eventual adhesions of the right lung to avoid damage to the visceral leaflet of the pleura, which may cause the occurrence of a postoperative air leak (Figs. 2, 3). The dissection and

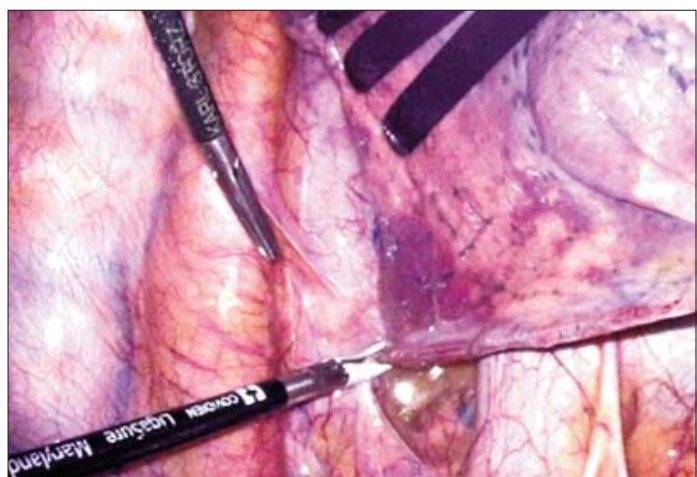

Figure 2. Incision of the triangular ligament of the lung

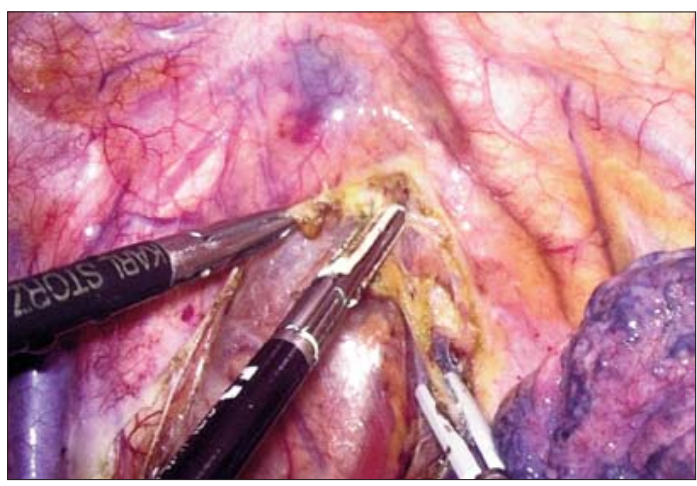

Figure 3. Incision of the mediastinal pleura at the upper thoracic aperture

isolation of the arch of azygos vein are facilitated by the presence of the Faucher tube in the esophagus, but for the introduction of the vascular stapler, it is necessary to retract the tube up in the upper esophagus. The Faucher tube is reintroduced into the distal esophagus to facilitate esophageal isolation with a Penrose tube. After cutting the arch of azygos vein, the esophagus is dissected circumferentially along its entire length from the upper thoracic aperture to the hiatal opening en bloc with the periesophageal lymphoid tissue (Figs. 4, 5, 6). The esophagus is released gradually, with fine hemostasis of vascular pedicles using the Ligasure instrument, while mediastinal lymphadenectomy is also performed (Figs. 7, 8, 9). If the thoracic duct is visible during the mediastinal dissection, it is clipped using metallic clips to prevent the chylothorax (Figs. 10, 11).

After the esophagus is complete released, pleural lavage is performed, haemostasis is controlled and two tubes are installed and 


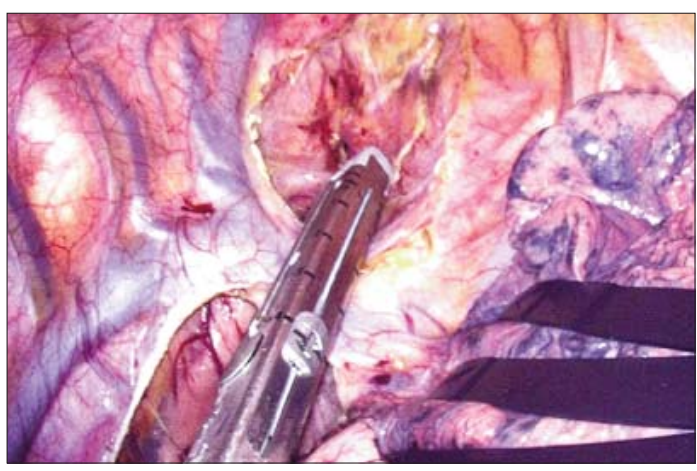

Figure 4. Sectioning of the azygos vein

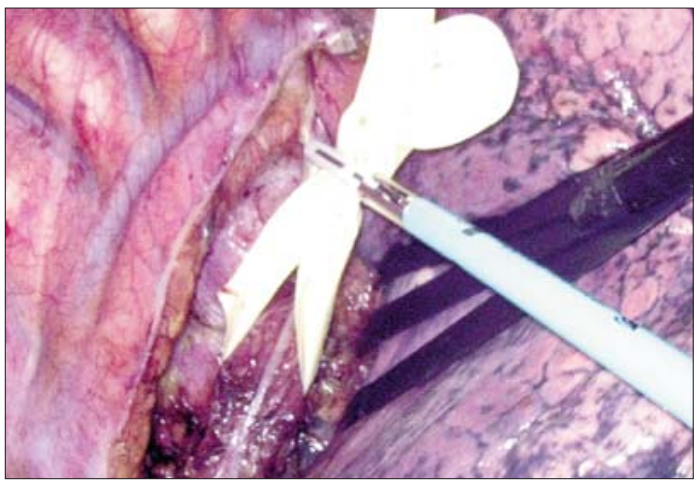

Figure 6. Isolation of esophagus

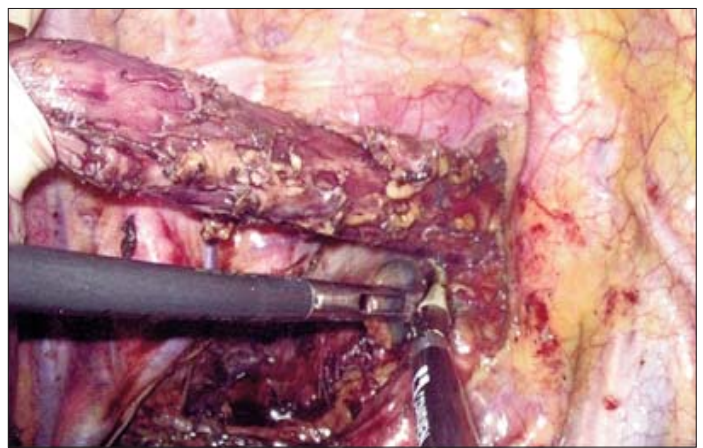

Figure 8. Mediastinal lymphadenectomy

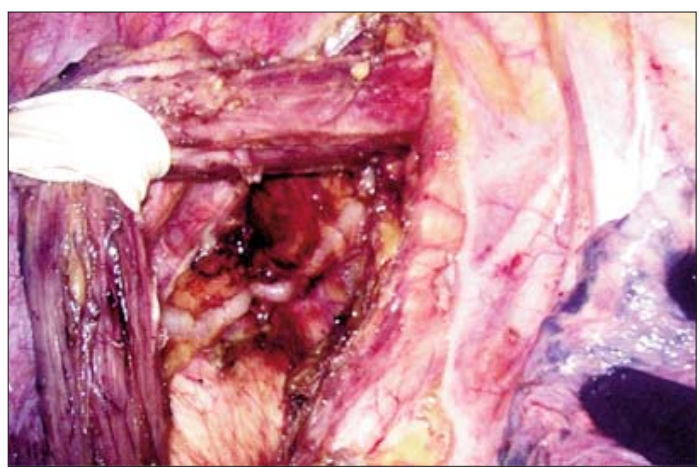

Figure 10. Identifying the thoracic duct above the arch of aorta

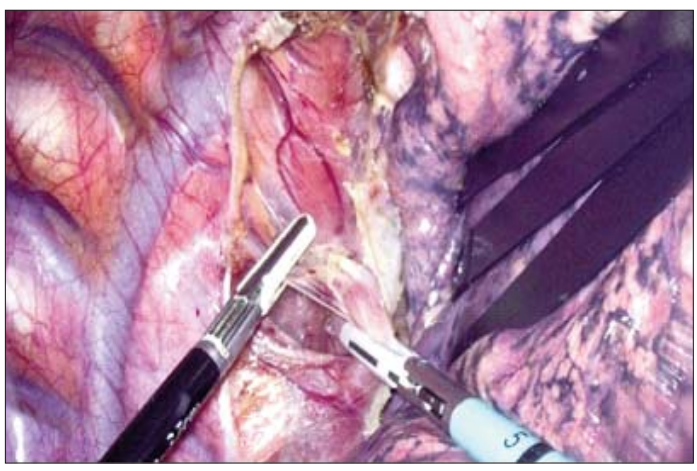

Figure 5. Sectioning of aorto-esophageal arteries

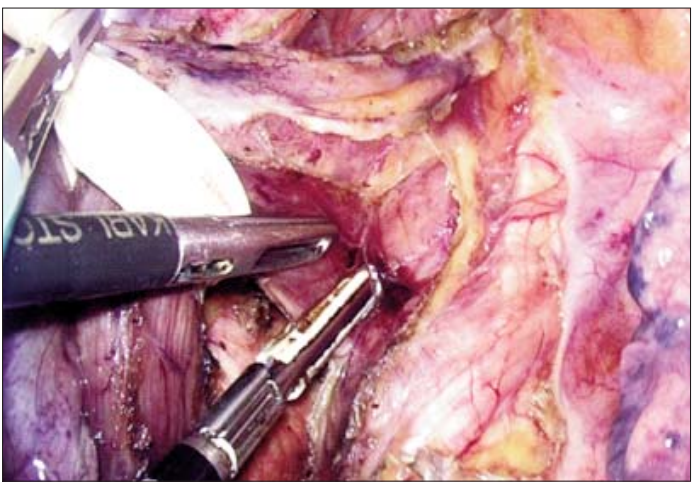

Figure 7. Dissection of upper thoracic esophagus

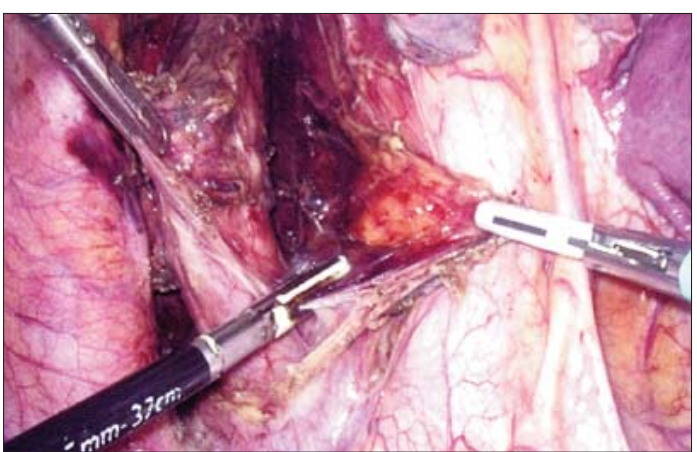

Figure 9. Dissection of lower thoracic esophagus

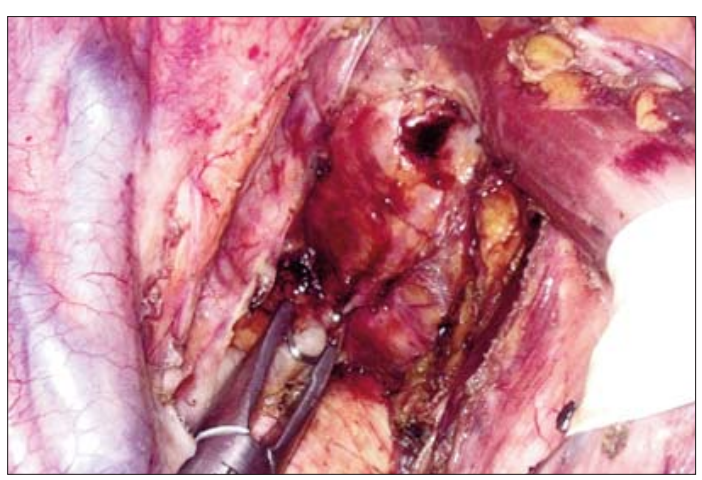

Figure 11. Clipping of thoracic duct 
connected to Béclaire drainage, one in the costophrenic sinus and the other in the apex. The chest cavity is closed, the lung is expanded under direct view and the instruments and trocars are extracted, the thoracic skin wounds are sutured (Fig. 12).

The Laparoscopic stage begins after the patient is positioned in French or American position (we did not notice significant differences between the positions). The Carlens selective orotracheal intubation tube is replaced with one with a single lumen. A minimal epigastric supraumbilical incision is performed and the peritoneal cavity is insufflated with a Veres needle followed by the insertion of the $12 \mathrm{~mm}$ optical trocar and the laparoscope. The position of the working trocars during the laparoscopic stage is as follows: a $2 \mathrm{~mm}$ trocar, subxiphoid for the EndoFan retractor; a $12 \mathrm{~mm}$ trocar, supraumbilical and lateral to the right midclavicular line; a $12 \mathrm{~mm}$ trocar, supraumbilical and lateral to the left midclavicular line; a $5 \mathrm{~mm}$ trocar in the left upper quadrant for inserting instruments used for traction and contertraction. After installing the working trocars, the peritoneal cavity is explored carefully to detect other pathologies or metastatic seeding, especially for distal esophageal neoplasms. The EndoFan is inserted into the subxiphoid trocar and helps to retract the left hepatic lobe from the working field and to expose the esophagogastric junction. If the patient had a feeding gastrostomy, it can be dismantled with an EndoGIA stapler or by simply suturing with Silk 3-0 yarns (Fig. 13).

The patient is placed in the Fowler position. The dissection opens the lesser sac by cutting the lesser omentum, the gastro-colic ligament (starting at its middle and continuing with the gastrosplenic and gastrophrenic ligament) and gastric posterior gastric adhesions with the pancreas. Then the stomach is mobilized on the greater and lesser curvature, with the protection of the marginal arterial arcades. The Leimer-Bertelli membrane is sectioned and the abdominal esophagus is isolated, combining the dissection plane with the thoracic plane, enlarging the esophageal hiatus by the

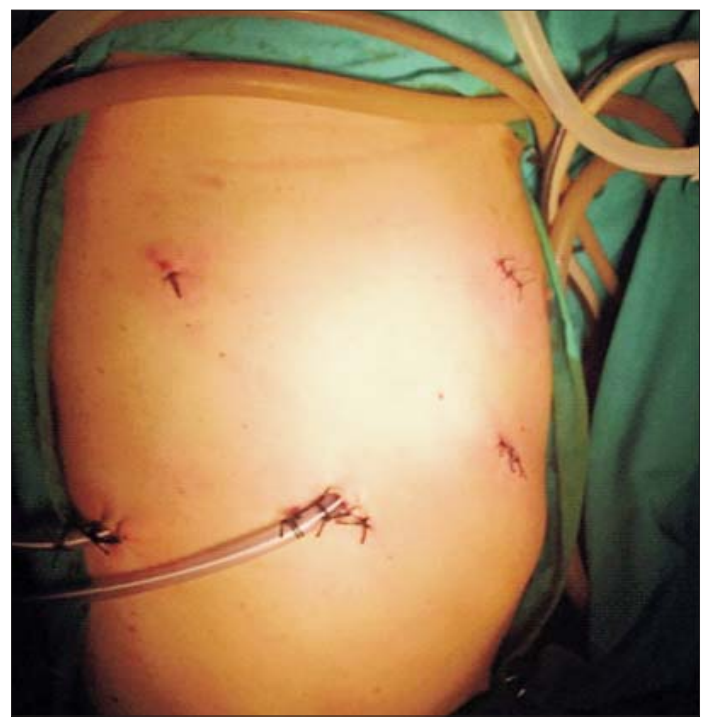

Figure 12. Postoperative aspect - thoracoscopic stage

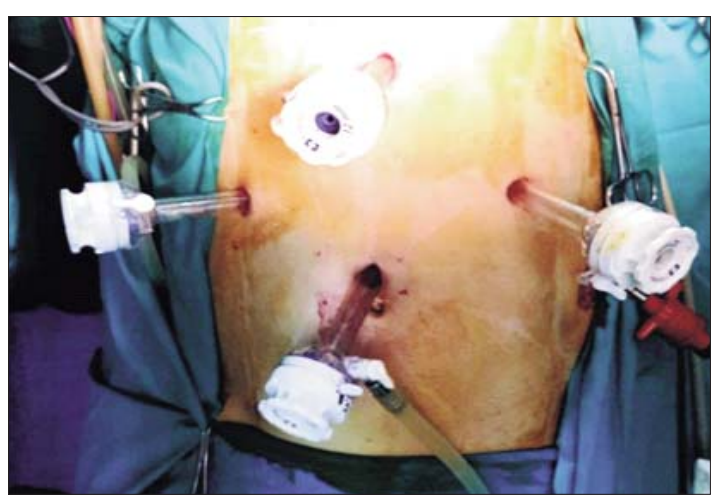

Figure 13. Position of the trocars during laparoscopic stage

section of the right and left diaphragmatic crus using the Ligasure. The stomach is retracted to the right and the elements of the left stomach pedicle are isolated (Figs. 14, 15, 16, 17).

Subsequent, the gastrocolic ligament is sectioned up to the antro-pyloric region conserving the right gastro-epiploic arcade. The laparoscopic gastric mobilization is continued by cutting the coronary pedicle with a vascular stapler at the origin of the left gastric artery from the celiac trunk and performing the perigastric lymphadenectomy while preserving the vascular pedicle of the graft, the right gastroepiploic pedicle (the thin right gastric artery is sectioned) (Figs. 18, 19). Kocher maneuver is practiced to further 


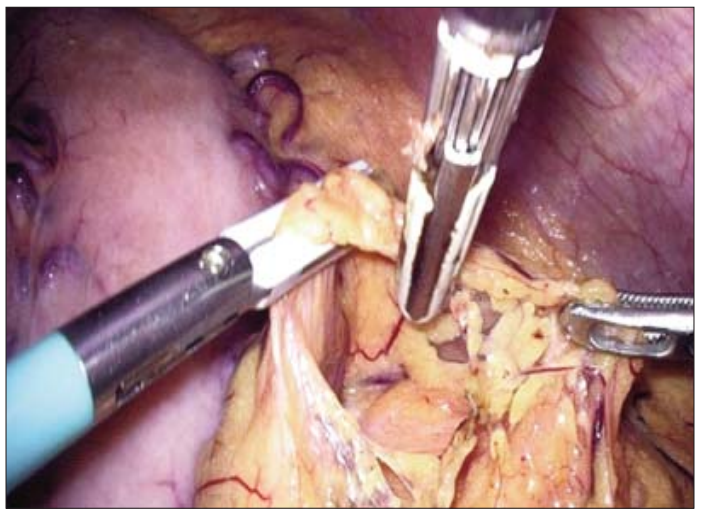

Figure 14. Sectioning of gastro-colic ligament

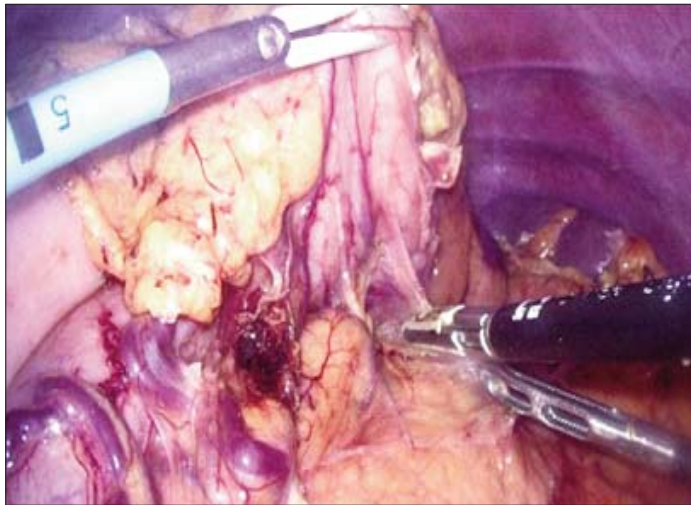

Figure 16. Dissection of posterior gastric adhesions

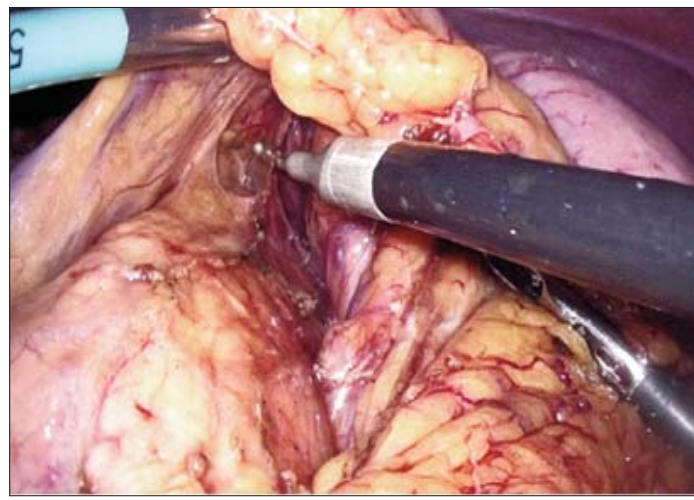

Figure 18. Perigastric lymphadenectomy

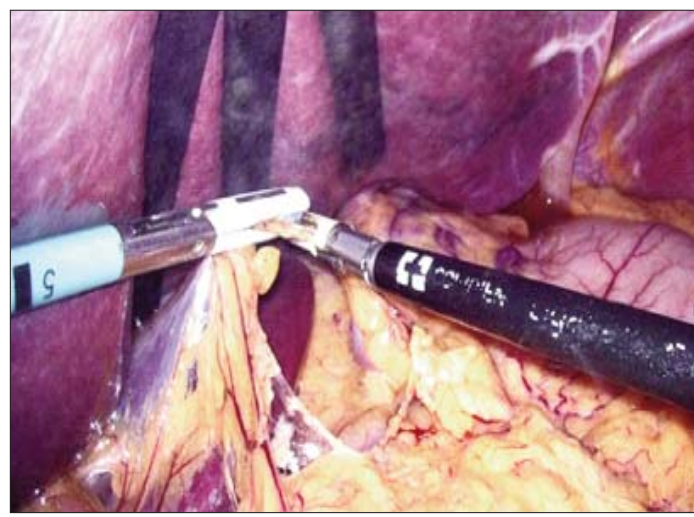

Figure 15. Sectioning of hepato-gastric ligament

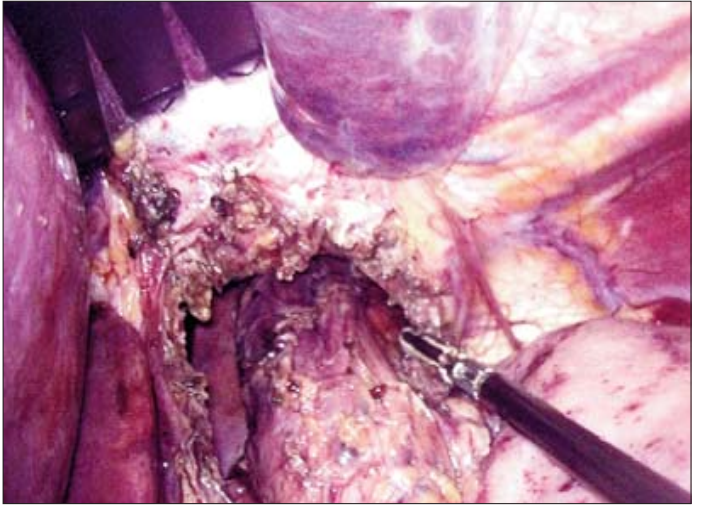

Figure 17. Partial sectioning of diaphragmatic crus for enlargement of the hiatus

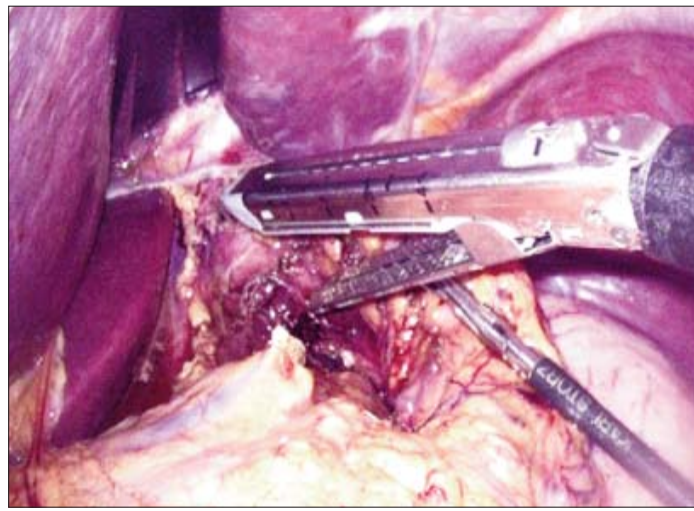

Figure 19. The left gastric pedicle section at the origin from the celiac trunk

the left vascular-nervous pedicle of the neck to the prevertebral fascia. The esophago-tracheal angle is highlighted and a carefully dissection is done between the esophagus and the tracheal membrane. Dissection of the cervical esophagus is performed step by step down to the upper 


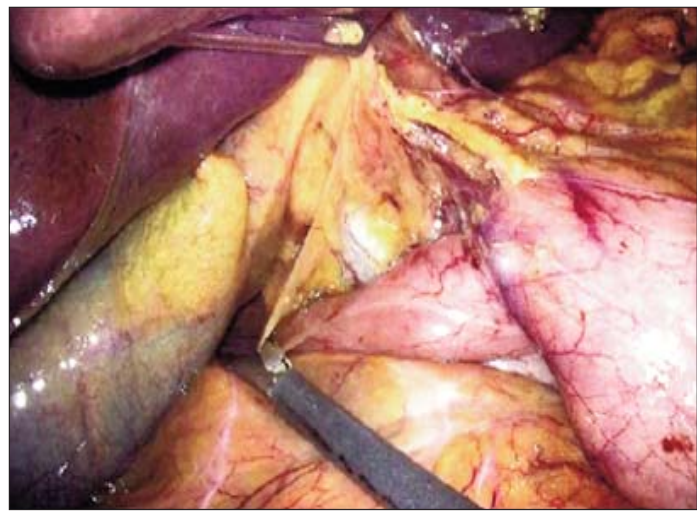

Figure 20. Duodeno-pancreatic detachment (Kocher manœuvre)

thoracic aperture, combining with the thoracic plane (the maneuver is facilitated by isolation using a Foley catheter), with protection of the trachea and the left recurrent nerve which requires to be identified. The esophagus is then cut over the jugular incision of the sternum ensuring the proximal cervical stump has sufficient length (Fig. 21).

For middle and superior thoracic esophageal tumors, using Akiyama technique, we mobilize the entire stomach using the Nakayama technique, and for the lower ones we create the gastric tube form the greater curvature using two GIA linear staplers with partial excision of the lesser curvature and the adjacent fat tissue which remain attached to the esophagectomy specimen.

In a totally minimally invasive fashion, the esophagectomy specimen together with the gastric conduit is ascended to the neck and extracted through the left cervical incision (Figs. 22, 23). The section of the esophagectomy specimen at the subcardial level is practiced with a linear GIA or EndoGIA stapler with a blue or green cartridge after anchoring it with some sutures and securing it to the cervical level and subsequent the specimen is sent to the final anatomopathological exam (Figs. 24, 31).

After cutting and closing the cardia with a linear stapler, the cervical esophago-gastric end-to-side cervical anastomosis is performed between the cervical esophagus and the gastric conduit with interrupted stitches of

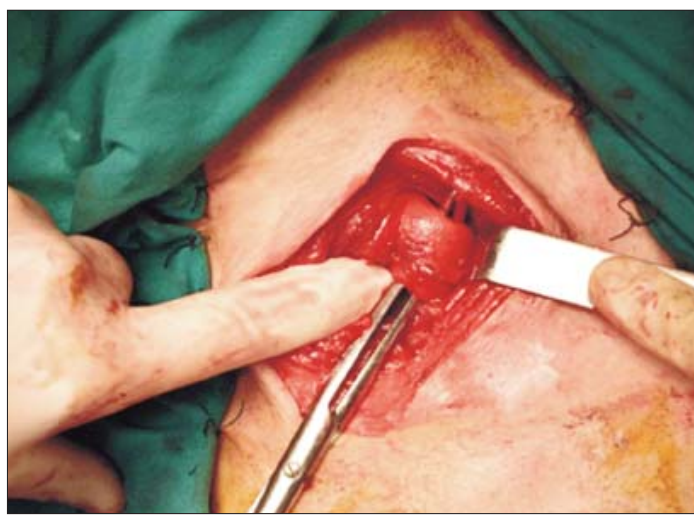

Figure 21. Left lateral neck dissection with esophagus isolation

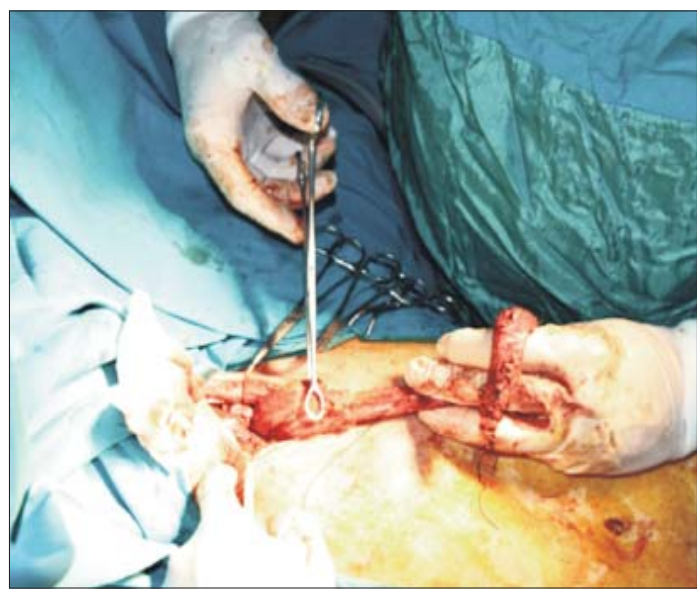

Figure 22. Extracting the esophagectomy specimen

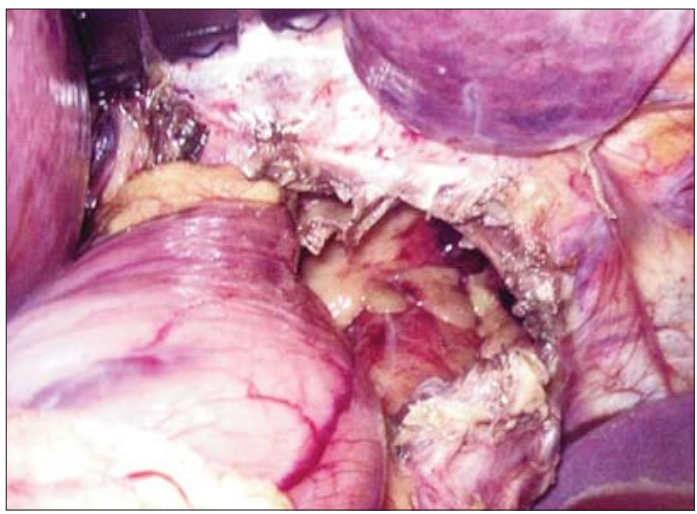

Figure 23. Gastric pull-up through hiatus

PDO 3-0 or Maxon 4-0 continuous suture. After the back layer is done, a nasogastric probe is passed into the ascensioned intrathoracic gastric graft. The anterior anastomotic layer is done in the same manner (Fig. 25). 


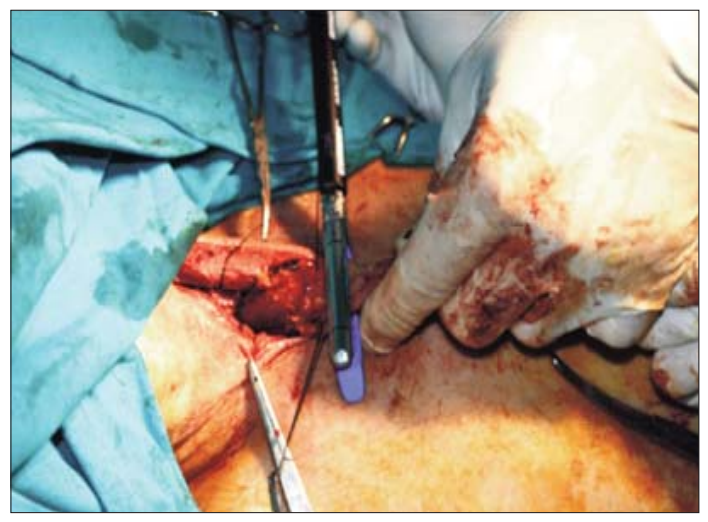

Figure 24. Cardia section

For extracorporeal preparation of the gastric graft, an epigastric mini-laparotomy is performed by extension the incision of the optical trocar. The cervical esophagus is sectioned at 3-4 cm above the upper thoracic aperture, the distal stump is closed with 2.0 Silk suture, the esophagectomy specimen is anchored to a Levine tube and is extracted with the stomach through the mini-laparotomy. The section of the cardia and the creation of gastric tube is done (depending on the chosen reconstruction technique) using a GIA stapler with a green or blue cartridge (depending on the thickness of the gastric wall). The resection area is reinforced with a 3-0 PDO continuous suture. The gastric conduit is anchored to a Levine tube at the proximal point of the fornix and is ascended trans-mediastinal by the pull-up technique in the former esophageal place. A gastrotomy is then performed at the fornix level and a wide esophagogastric single layer anastomosis is done in the already mentioned fashion (Figs. 26, 27, 28).

After finishing the anastomosis, a lavage with betadine serum is performed and the cervical wound is sutured. We do not practice routine cervical drainage of cervical anastomoses when we use gastric conduit. We return to the abdomen where a feeding jejunostomy is mounted on the Foley $18 \mathrm{Ch}$ catheter in the first $20 \mathrm{~cm}$ from Treitz angle on the first jejunal loop which is extracted through incision in the left upper quadrant after is fixed with Silk 3-0 stitches to the parietal peritoneum (modified Stamm

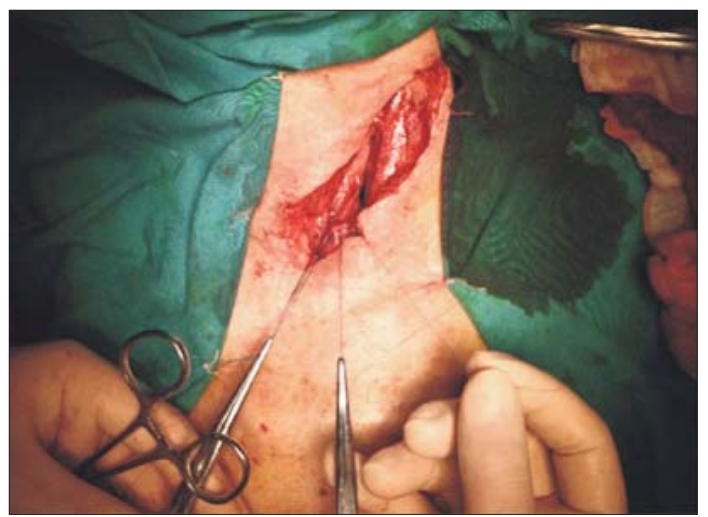

Figure 25. Cervical end-to-side esophago-gastric anastomosis

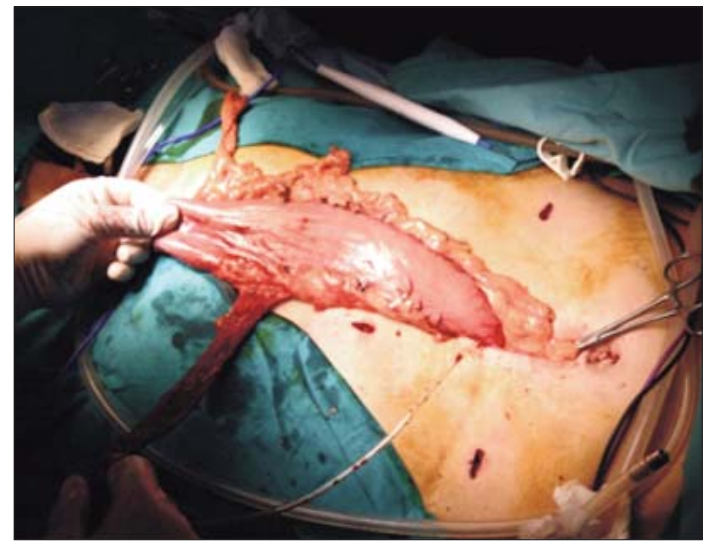

Figure 26. Measurement of the length of the gastric conduit exteriorized through an epigastric mini-laparotomy

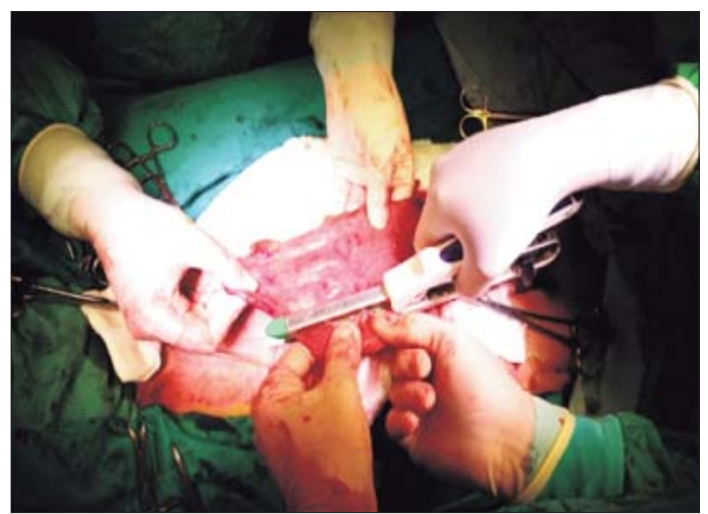

Figure 27. Extracorporeal preparation of the gastric conduit

technique). Jejunostomy can be mounted in the classical manner, the mini-laparotomy allows for a sufficient working space or by minimally invasive approach. 


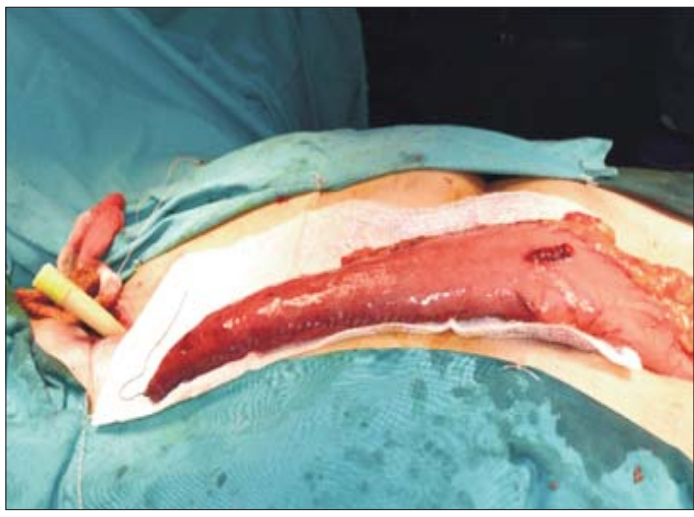

Figure 28. Gastric tube (the site of the former feeding gastrostomy is sutured)

For laparoscopic jejunostomy we use incision of the trocar located on the left midclavicular line. After the first jejunal loops is anchored inside to the parietal peritoneum close to the incision of the trocar, we make a purse string with a 3-0 Silk stitch. The intestinal wall is incised and the Foley catheter is inserted through the mentioned trocar. We check the position of the catheter in the jejunum both visually and by instillation with a syringe with physiological serum. The jejunal loop is additionally anchored in several points to the anterior abdominal wall, and the trocar is extracted and the jejunostomy is secured to the skin as well (Fig. 29).

Practicing a Heinecke-Mikulicz pyloroplasty or a pyloric anterior myomectomy is often optional, while the insertion of feeding tube is a rule to facilitate enteral nutrition in the postoperative period. We practice lavage of the peritoneal cavity with betadine serum and drainage at the diaphragmatic hiatus, with a drain tube exteriorized by the working trocar incision on the right midclavicular line. Trocars wounds are sutured after their extraction is visualized or epigastric mini-laparotomy is closed in the anatomical layers (Fig. 30).

\section{Results}

The average duration of surgery is 300 minutes with an intraoperative blood loss of approximately $250-300 \mathrm{ml}$. Patients are extubated at the end of surgery and a chest $\mathrm{X}$-ray is

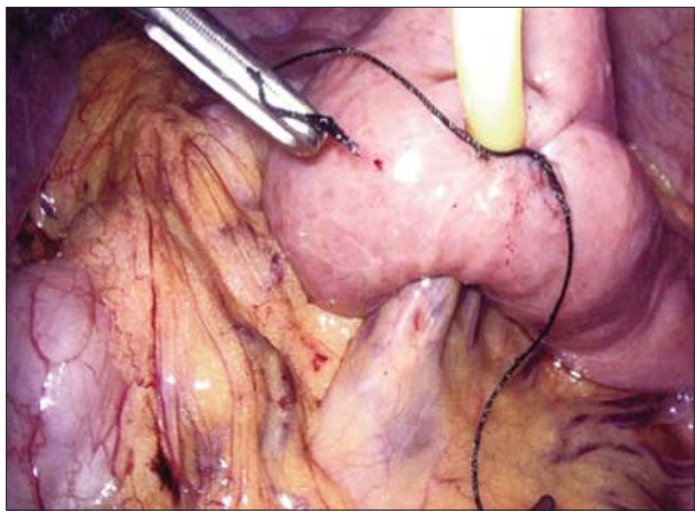

Figure 29. Laparoscopically assisted insertion of feeding jejunostomy

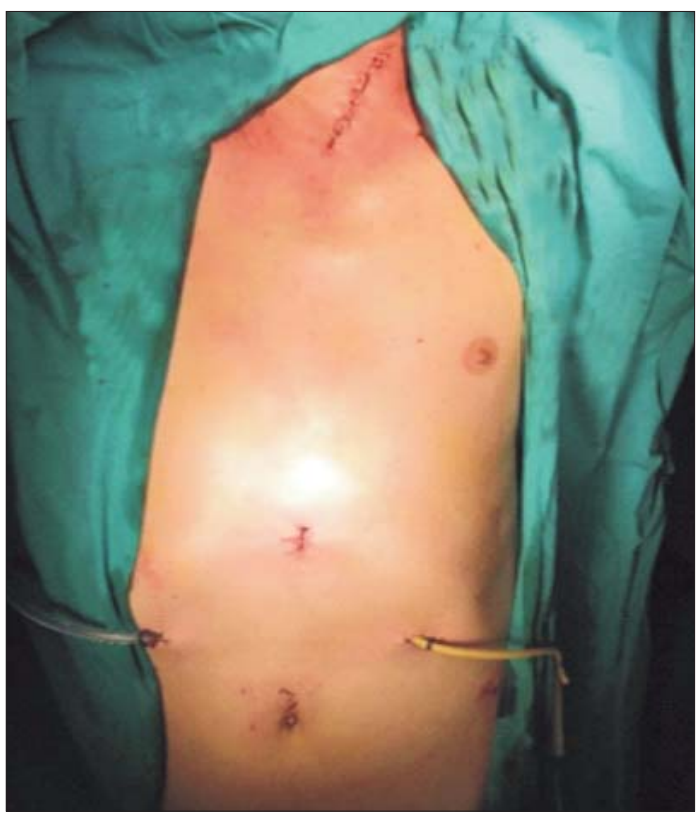

Figure 30. Postoperative aspect - laparoscopic and neck stage

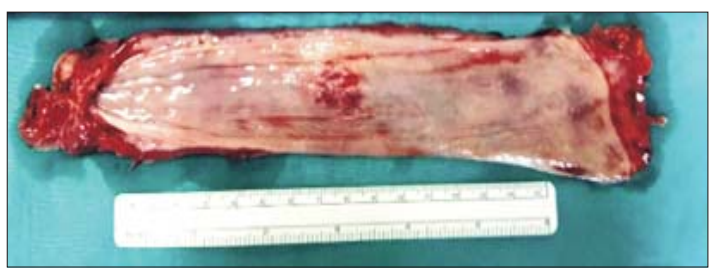

Figure 31. Subtotal esophagectomy specimen

performed to assess pulmonary expansion and then they are transferred for monitoring in the ICU department.

Patients are treated in ICU for 2 days using 
an integrated post-esophagectomy care protocol, which includes intensive physiotherapy, early mobilization and enteral nutrition are initiated on the first postoperative day on the feeding jejunostomy to prevent postoperative complications.

The trans-anastomotic nasogastric tube used for gastric graft drainage is maintained in the first postoperative days depending on the quantity of the drainage. A digestive transit with an oral contrast agent is performed on the 5th postoperative day for evaluation of esofagogastric anastomosis and function of gastric graft.

Patients are discharged on the $10^{\text {th }}$ postoperative day and they use feeding jejunostomy for an additional food intake. The jejunostomy is removed after a clinical and paraclinical re-evaluation with a barium swallow transit one month after surgery. Patients are re-evaluated every 3 months in the first year, every 6 months in the second year, and every year thereafter, or whenever is necessary, if postoperative complications arise.

\section{Intraoperative Incidents and Accidents}

During the thoracoscopic stage, the introduction of the optical trocar far too low is possible with consequent damage the diaphragm muscle or even the right hepatic lobe when is inserted intrabdominal. Also, the use of the Veres needle increases the risk of damage of lung parenchyma with a postoperative air leak if pleural adhesions are present. Mediastinal dissection predisposes to incidents that can be recognized intraoperatively (hemorrhage from large intrathoracic vessels, damage to the arch of azygos vein or tracheal membrane) that can be treated by minimally invasive approach or sometimes is necessary conversion to classical surgery (average conversion rate reported in the literature is $5-7 \%$ ). Also, between the azygos vein and the esophagus are encountered aorticoesophageal vessels, which, if not dissected carefully, their damage can cause a hematoma that makes difficult to interpret local anatomy in an important dissection area. The consequences of intraoperative accidents become evident postoperative (chylothorax after the section of the thoracic duct, left recurrent nerve palsy), they increase postoperative morbidity and require specific management.

Laparoscopic mobilization of the stomach is associated with bleeding incidents that may affect the viability of the gastric graft and may compromise esophageal reconstruction (32).

\section{Postoperative Complications}

When we have suspicion about the viability of the gastric conduit, the esophageal substitute can be evaluated endoscopically, starting from the first postoperative day, if all other noninvasive diagnostic methods have been excluded. The indication should be very clear, the endoscopy is an invasive and risky investigation after esophagectomy, but is considered feasible if is performed by an experienced endoscopist (33).

If vital complications associated with volvulus, ischemia or necrosis of the gastric reservoir occur, a re-intervention is urgently performed and the gastric conduit is removed and a cervical esophagostomy is done. We use the ClavienDindo classification and the recommendations of the Esophagectomy Complications Consensus Group (ECCG) to evaluate postoperative complications $(34,35)$.

\section{Discussions}

Esophageal reconstruction aims to restore digestive continuity and the functional outcome will be appreciated by the postoperative quality of life of the patients (the swallowing is close to normal, digestive transit is good in the gastric graft and the absence of reflux) (36).

Planning the extension of esophageal resection and choosing the type of esophageal substitute is based on anatomical criteria, availability and applicability (sufficient length, adequate vascular support, past history of gastric resections), age and patient prognosis (malignant pathology) (37-38).

Haverkamp et al. conducted an international study in 49 countries in coordination with the International Society for Diseases of Esophagus (ISDE) and they found an increased frequency 
of using of MIE in current practice from $14 \%$ in 2007 to $43 \%$ in 2014 . The two-field lymphadenectomy is the most practiced in $86 \%$ of centers, and the gastric reservoir is the preferred esophageal substitute (95\%) for reconstruction. High intrathoracic anastomosis is frequently used, and cervical anastomosis has decreased from $87 \%$ in 2007 to $54 \%$ at present. Also, the use of mechanical devices for cervical anastomosis (36\%) increased, while the intrathoracic anastomosis is still performed manually $(23 \%)$ in some centers (39).

In our clinic, the use of minimally invasive esophagectomy for the treatment of esophageal cancer has simplified postoperative care, has reduced lung complications and hospital stay with a faster social reintegration. The long-term oncological results are being evaluated. The augmented 3D High Definition image, introduced two years ago in our clinic, provides an excellent visual field, that allows accurate identification of dissection plans and extensive periesophageal and perigastric lymphadenectomy. During the first minimally invasive interventions we performed an epigastric minilaparotomy which allowed extraction of the esophagectomy specimen and extracorporeal preparation of the gastric tube, recommended by some authors to reduce the risks associated with the MIE learning curve. We did not experience any difficulty in preparing the gastric graft in patients who had feeding gastrostomy, the closure the gastrostomy hole allows for good healing without fistulas, because is located distally in a area with rich blood supply. In patients where the surgeon appreciates an $\mathrm{R} 0$ resection, the gastric graft is ascended through the posterior mediastinum in the bed of the former esophagus.

The technique of sectioning of cervical esophagus is important for the viability of anastomosis, given the absence of a proper serosa. We recommend the cutting of the muscular fibers circumferentially with highlighting the esophageal mucosa and then sectioning is done at the desired level to obtain enough material for the anastomosis given the tendency of the muscular fibers to retract, thus increasing the tension in the anastomosis. Unlike the rest of the digestive tract, the esophageal mucosa being a non-keratinized stratified squamous epithelium is a good material for anastomosis. The anastomosis must be wide enough to prevent anastomotic stenosis following the healing process (40).

It is important to mention that if the cervical anastomosis is too proximal, reaching up to the pharynx, the swallowing is more hesitant and associated with a higher risk of tracheobronchial aspiration. Also, the cervical anastomotic leak does not imply a vital prognosis, eventual healing with stenosis is treated with endoscopic dilations (41).

The gastric tube (which is closer to the anatomical shape of the esophagus) has a shorter time for transit of food and a reduced gastric acid secretion, which results in a decreased incidence of reflux compared to the use of the entire stomach (42-44).

A large intrathoracic stomach determines partial right atelectasis of the right lung with decreased pulmonary ventilation and increased the risk of lung infections. Reducing stomach volume by creating the gastric tube decreases the incidence of intrathoracic stomach syndrome (45).

It is estimated that the tubular stomach has an increased blood supply in the anastomosis, but venous return and microvascular circulation are still deficient and may be involved in the occurrence of anastomotic fistula (46). Although, the use of the gastric tube is associated with several advantages, still there are no statistical differences in the rate of anastomotic fistula and anastomotic stenosis compared to the use of the whole stomach.

Regarding the size of the gastric tube, when was used a narrow gastric tube (diameter 3-4 $\mathrm{cm})$, Luketich et al. reported a high incidence of gastric necrosis and anastomotic leakage and when was used a wider gastric conduit (5-6 cm) was observed a decrease in the anastomotic complications (47).

The partial ischemic preconditioning of the stomach by the laparoscopic approach with cutting of the arterial pedicles except for the right gastroepiploic artery 2 weeks before the esophageal reconstruction surgery was a 
brave and ambitious initiative in the attempt to improve the vascularization of the gastric reservoir. A better microvascularization was found in the proximal stomach, but there was no statistically significant influence on the rate of anastomotic fistula (48).

In classical surgery, the viability of the graft is assessed intraoperatively by visual inspection of its color and by palpation of the feeding pedicle pulse. The use of indocyanine green angiography has been proposed for the objective evaluation of blood circulation of the gastric reservoir during laparoscopic mobilization and has been shown to be useful for preventing the injury of vascular pedicle during the learning curve and for choosing the optimal site of anastomosis based on the vascular model (49). In a study conducted in 150 patients by Zehetner et al, when the anastomosis was performed in the optimal perfusion area, the rate of anastomotic fistula was significantly lower ( $2 \%$ vs. $45 \%, \mathrm{p}<0.0001)$ (50). The assessing the vascularization of the gastric graft with angiography with indocyanine green should become a routine investigation in esophageal reconstruction.

As the delayed emptying of the gastric graft is resumed in the first few weeks postoperatively, we do not recommend routinely performing of pyloroplasty of the stomach, which is disconnected from the vagal and sympathetic nervous system. Pyloroplasty influences the gastric emptying and may cause biliary reflux. Studies have not established any correlation between pyloroplasty and anastomotic fistula, postoperative lung complications, length of hospital admission, or general perioperative morbidity (51).

In the analysis of postoperative outcomes, it was found that 90-days mortality is a more accurate indicator of the quality of management of patients with reconstructive esophagectomy compared to 30-days postoperative mortality, in a study by $\mathrm{In} \mathrm{H}$ et al. in 977 hospitals and including 15,796 esophagectomy ( $8.9 \%$ vs. $4.2 \%$, $\mathrm{P}<0.0001$ ) (52). Also, re-admission within the first 30 days of surgery is associated with increased mortality at 90 days postoperatively, so it is important to identify conditions that predispose to vital risk and to promptly respond for their treatment (53).

The long-term oncological results of esophagectomy performed by the minimally invasive approach were analyzed in randomized clinical trials (TIME, MIRO and ROBOT) and have been recently published. Thus, 3-year survival was $42.9 \%$ MIE vs $41.2 \%$ OE in the TIME trials, $67 \%$ MIE vs $55 \%$ OE in the MIRO study, and overall survival at 5 years was $42 \%$ in the ROBOT study (54-44). In conclusion, minimally invasive esophagectomy and reconstruction with stomach is a laborious operative technique with a long learning curve, requires a technically demanding base which is difficult to access and is recommended to be performed in centers specialized in esophageal pathology.

\section{Conflict of Interest}

The authors declare no conflicts of interests.

\section{Author's Contributions}

The first and second author contributed equally to this article.

\section{References}

1. Torek F. First successful case of resection of the esophagus. JAMA 1913;60:1533.

2. S. Constantinoiu. Istoricul chirurgiei esofagiene. În: Constantinoiu S, Cordos I, Ciuce C, Scripcariu V, editors. Tratat de Patologie și Chirurgie Esofagiană. București:Editura Academiei Române. 2017. p. 27-44.

3. Beck C, Carrel A. Demonstration of specimens illustrating a method of formation of a prethora thic esophagus. Illi Med J. 1905; 7:463-464 1115.

4. Jianu A. Gastrostomie und osophagoplastik. Dtsch Z Chir. 1912; 118:383-90

5. Kirschner M. Ein neues Verfahren der Ösophagusplastik. Archiv für klinische Chirurgie 1920;114:2-59.

6. Ohsawa T. Surgery of the oesophagus. Arch Jap Chir. 1933;10:60595.

7. Lewis I. The surgical treatment ofcarcinoma ofthe oesophagus. $\mathrm{Br}$ J Surg. 1946;34:18-31

8. Gavriliu D, Georgescu L. Esofagoplastia direct cu material gastric (procedeu personal). Rev St Med. 1951;3:33

9. Garlock JH, Klein SH. The surgical treatment of carcinoma of the esophagus and cardia; an analysis of 457 cases. Ann Surg. 1954; 139(1):19-34.

10. Sweet RH. Late results of surgical treatment of carcinoma of the esophagus. JAMA. 1954;155:422-5.

11. Nakayama K. Statistical review of 5 year survivals after surgery for carcinoma of esophagus and cardiac portion of stomach. Surgery $1959 ; 45: 883-9$ 
12. McKeown KC. Total three-stage oesophagectomy for cancer of the oesophagus. Br J Surg. 1976;63(4):259-62.

13. Turner GC. Excision of thoracic esophagus for carcinoma with contructuin of extrathoracic gullet. Lancet. 1933;2:1315.

14. Orringer MB, Sloan H. Esophagectomy without thoracotomy. J Thorsc Cardiovasc Surg 1978;76:643-654.

15. Akiyama $H$. Principles of surgical treatment for carcinoma of the esophagus. Ann Surg 1981:194:438-46.

16. Lea R. In: Hurt RL, ed. Management of oesophageal carcinoma. London: Springer, 1989:157-86.

17. McKeown KC. The surgical treatment of carcinoma of the oesophagus. J R Coll Surg Edinb 1985; 30:1-14

18. Kobayashi S, Kanetaka K, Nagata Y, Nakayama M, Matsumoto R, Takatsuki $M$, et al. Predictive factors for major postoperative complications related to gastric conduit reconstruction in thoracoscopic esophagectomy for esophageal cancer: a case control study. BMC Surg. 2018;18(1):15.

19. Cuschieri A, Shimi S, Banting S. Endoscopic oesophagectomy through a right thoracoscopic approach. J R Coll Surg Edinb. 1992; $37(1): 7-11$

20. Dutch Institute for Clinical Auditing. DICA Jaarrapportage 2016 Accessed June 10, 2018. https://dica.nl/jaarrapportage- 2016/duca

21. McAnena OJ, Rogers J, Williams NS. Right thoracoscopically assisted oesophagectomy for cancer. Br J Surg. 1994;81(2):236-8.

22. Tapias LF, Morse CR. Minimally invasive Ivor Lewis esophagectomy: description of a learning curve. J Am Coll Surg. 2014;218(6):1130-40

23. Gisbertz SS, Hagens ERC, Ruurda JP, Schneider PM, Tan LJ, Domrachev SA, et al. The evolution of surgical approach for esophageal cancer. Ann N Y Acad Sci. 2018 Sep 7. doi: 10.1111/ nyas.13957.

24. Zhang W, Yu D, Peng J, Xu J, Wei Y. Gastric-tube versus wholestomach esophagectomy for esophageal cancer: A systematic review and meta-analysis. PLoS One. 2017;12(3):e0173416.

25. Pierie JP, de Graaf PW, van Vroonhoven TJ. The vascularization of a gastric tube as a substitute for the esophagus is affected by its diameter. Dis Esophagus 1998;11(4):231-235

26. Collard JM, Tinton N, Malaise J, Romagnoli R, Otte JB, Kestens PJ Esophageal replacement: gastric tube or whole stomach? Ann Thorac Surg 1995;60(2):261-267.

27. Shu YS, Sun C, Shi WP, Shi HC, Lu SC, Wang K. Tubular stomach or whole stomach for esophagectomy through cervico-thoracoabdominal approach: a comparative clinical study on anastomotic leakage. Ir J Med Sci 2013; 182(3):477-480.

28. Ionescu AN, Ghita C, Achim IF, Constantin A, Gheorghe M, Constantinoiu S, et al. Minimally invasive esophagectomy through modified McKeown triple approach with esophageal reconstruction and gastric pull-up for thoracic esophageal carcinoma - case report. Journal of Surgical Sciences; 2016;3(2):83-91.

29. Edge SB BD, Compton CC, Fritz AG, Greene FL, Trotti A. AJCC cancer staging manual. 7th ed. New York: Springer-Verlag; 2009. p.103-15.

30. Lewis SJ, Andersen HK, Thomas S. Early enteral nutrition within $24 \mathrm{~h}$ of intestinal surgery versus later commencement of feeding: a systematic review and meta-analysis. J Gastrointest Surg. 2009; 13(3):569-75

31. Decker G, Coosemans W, De Leyn P, Decaluwé H, Nafteux P, Van Raemdonck D, et al. Minimally invasive esophagectomy for cancer. Eur J Cardiothorac Surg. 2009:35(1):13-20; discussion 20-1.

32. Ramage L, Deguara J, Davies A, Hamouda A, Tsigritis K, Forshaw $M$, et al. Gastric tube necrosis following minimally invasive oesophagectomy is a learning curve issue. Ann R Coll Surg Engl. 2013;95(5):329-34

33. Fujiwara H, Nakajima Y, Kawada K, Tokairin Y, Miyawaki Y, Okada T, et al. Endoscopic assessment 1 day after esophagectomy for predicting cervical esophagogastric anastomosis-relating complications. Surg Endosc. 2016;30(4):1564-71

34. Dindo D, Demartines $N$, Clavien PA. Classification of surgical complications: a new proposal with evaluation in a cohort of 6336 patients and results of a survey. Ann Surg. 2004;240:205-213.

35. Low DE, Alderson D, Cecconello I, Chang AC, Darling GE, D'Journo $\mathrm{XB}$, et al. International Consensus on Standardization of Data Collection for Complications Associated With Esophagectomy: Esophagectomy Complications Consensus Group (ECCG). Ann Surg. 2015;262(2):286-94.

36. Predescu D, Constantinoiu S. Esophageal Reconstruction with the Stomach, a Functional Dilemma? Chirurgia (Bucur). 2018;113(1):83-94.

37. Cordos I, Constantinoiu S et al. Reconstructia esofagului cu stomac în cancerul esofagian. În: Constantinoiu S, Cordos I, Ciuce C, Scripcariu V, editors. Tratat de Patologie și Chirurgie Esofagiană. Bucuresti: Editura Academiei Române; 2017. p 687-691.

38. Wayne Hofstetter. Options for Esophageal Replacement in Adult Chest Surgery. David J. Sugarbaker, et al. Adult Chest Surgery second edition. McGraw-Hill Education, USA, 2015.

39. Haverkamp L, Seesing MFJ, Ruurda JP, Boone J, Hillegersberg R. v. Worldwide trends in surgical techniques in the treatment of esophageal and gastroesophageal junction cancer. Diseases of the Esophagus. 2017; 30:1-7.

40. Achim F, Constantinoiu S. Recent Advances in Minimally Invasive Esophagectomy. Chirurgia (Bucur). 2018;113(1):19-37.

41. K Ben-David, A Fullerton, G Rossidis. Prospective Comprehensive Swallowing Evaluation of Minimally Invasive Esophagectomies with Cervical Anastomosis: Silent Versus Vocal Aspiration. J Gastrointest Surg. 2015;19:1748-1752.

42. Barbera L, Kemen M, Wegener M, Jergas M, Zumtobel V. Effect of site and width of stomach tube after esophageal resection on gastric emptying. Zentralbl Chir. 1994;119(4):240-244.

43. Bonavina L, Anselmino M, Ruol A, Bardini R, Borsato N, Peracchia A. Functional evaluation of the intrathoracic stomach as an oesophageal substitute. Br J Surg. 1992;79(6):529-532.

44. Domergue J, Veyrac M, Huin-Yan S, Rouanet P, Collet H, Michel H, et al. $\mathrm{pH}$ monitoring for 24 hours of gastroesophageal reflux and gastric function after intrathoracic gastroplasty after esophagectomy. Surg Gynecol Obstet. 1990;171(2):107-110.

45. Chen SW, Fu XN, Xu CC, Zhang N, Pan XJ, Liu MY. Influence of Gastric Tube Reconstruction on Gastroesophageal Reflux after Esophagectomy for Esophageal Carcinoma. Acta Med Univ Med Tongji. 2011;40(5):593-596.

46. Panebianco V, Francioni F, Anzidei M, Anile M, Rolla M, Passariello R. Magnetic resonance- fluoroscopy as long-term follow-up examination in patients with narrow gastric tube reconstruction after radical esophagectomy. Eur J Cardiothorac Surg. 2006;30(4): 663-668.

47. Luketich JD, Alvelo-Rivera M, Buenaventura PO, Christie NA, McCaughan JS, Litle VR, et al. Minimally invasive esophagectomy: outcomes in 222 patients. Ann Surg. 2003; 238(4):486-94; discussion 494-5.

48. Yuan Y, Duranceau A, Ferraro P, Martin J, Liberman M. Vascular conditioning of the stomach before esophageal reconstruction by gastric interposition. Dis Esophagus. 2012;25(8):740-9.

49. Rino Y, Yukawa N, Sato T, Yamamoto N, Tamagawa H, Hasegawa S, et al. Visualization of blood supply route to the reconstructed stomach by indocyanine green fluorescence imaging during esophagectomy. BMC Med Imaging. 2014:14:18.

50. Zehetner J, DeMeester SR, Alicuben ET, Oh DS, Lipham JC, Hagen JA, et al. Intraoperative Assessment of Perfusion of the Gastric Graft and Correlation With Anastomotic Leaks After Esophagectomy. Ann Surg. $2015 ; 262(1): 74-8$.

51. Constantinoiu S. Achim F. Esofagectomia minim invaziva. În: Constantinoiu S, Cordos I, Ciuce C, Scripcariu V, editors. Tratat de Patologie și Chirurgie Esofagiană. București, Editura Academiei Române; 2017. p. 649-676.

52. In H, Palis BE, Merkow RP, Posner MC, Ferguson MK, Winchester $\mathrm{DP}$, et al. Doubling of 30-Day Mortality by 90 Days After Esophagectomy: A Critical Measure of Outcomes for Quality 
Improvement. Ann Surg. 2016;263(2):286-91.

53. Hu Y, McMurry TL, Stukenborg GJ, Kozower BD. Readmission predicts 90-day mortality after esophagectomy: Analysis of Surveillance, Epidemiology, and End Results Registry linked to Medicare outcomes. J Thorac Cardiovasc Surg. 2015;150(5):1254-60.

54. Biere SS, van Berge Henegouwen MI, Maas KW, Bonavina L, Rosman C, et al. Minimally invasive versus open oesophagectomy for patients with oesophageal cancer: a multi-centre, open-label, randomised controlled trial. Lancet. 2012; 379(9829):1887-92.

55. Straatman J, van der Wielen N, Cuesta MA, Daams F, Roig Garcia J, Bonavina $L$ et al. Minimally invasive versus open esophageal resection: three-year follow-up of the previously reported randomized controlled trial: The TIME Trial. Ann Surg.2017;266(2):232-6.

56. Mariette C, Meunier B, Pezet D, Dalban C, Collet D, Thomas PA, et al. Hybrid minimally invasive versus open oesophagectomy for patients with oesophageal cancer: A multicenter, open-label, randomized phase III controlled trial, the MIRO trial. Journal of
Clinical Oncology. 2015;33:3_suppl:5-5.

57. Mariette C, Markar S, Dabakuyo-Yonli TS, Meunier B, Pezet D, Collet $\mathrm{D}$, et al. Hybrid minimally invasive vs. open esophagectomy for patients with esophageal cancer: Long-term outcomes of a multicenter, open-label, randomized phase III controlled trial, the MIR0 trial. Annals of Oncology. 2017;28(suppl_5):v605-v649.

58. van der Sluis PC, Ruurda JP, van der Horst S, Verhage RJ, Besselink MG, Prins MJ, et al. Robot-assisted minimally invasive thoraco-laparoscopic esophagectomy versus open transthoracic esophagectomy for resectable esophageal cancer, a randomized controlled trial (ROBOT trial). Trials. 2012;13:230.

59. van der Sluis PC, van der Horst S, May AM, Schippers C, Brosens LAA, Joore HCA, et al. Robot-assisted Minimally Invasive Thoracolaparoscopic Esophagectomy Versus Open Transthoracic Esophagectomy for Resectable Esophageal Cancer: A Randomized Controlled Trial. Ann Surg. 2018 Oct 10. doi: 10.1097/ SLA. 0000000000003031. [Epub ahead of print] 